\title{
Crisis communication characteristics and errors: A case study
}

\author{
Martial Pasquier \\ Swiss Graduate School of Public Administration (IDHEAP), Lausanne \\ Etienne Fivat \\ Swiss Graduate School of Public Administration (IDHEAP), Lausanne
}

\begin{abstract}
In 2006, events surrounding the University of Geneva led to the resignation of its executive board, and a political reform of the institution. This case constitutes a typical example of where a crisis is strengthened, and even created, by inappropriate information-management. Such situations, in which material damages and personal harm are generally quite limited, are increasingly frequent and have a particularly important impact on public trust in political and administrative institutions. The main aim of this paper is to identify the characteristics of this type of crisis, and errors linked to it from a media-communications perspective. This will be done through an analysis of publications in four different newspapers, as well as of official documents and statements from the period during which the crisis took place and in the months that followed.
\end{abstract}

\section{Introduction}

On April 9, 2006, the Sunday paper Le Matin Dimanche published an article entitled, "Scandale à l'Uni: des profs menaient la grande vie aux frais de l'Etat" (Scandal at the University: profs living lavishly at the state's expense), in which it revealed the contents of an audit report on the University of Geneva conducted by the financial inspection agency of the state of Geneva. This article sparked a crisis lasting several months that led to the resignation of all members of the executive board of the university ${ }^{1}$ and to a reform of the university by political authorities.

While crisis management and communication related to catastrophes, accidents or major incidents have been the subject of numerous studies, - i.e. situations in which it is necessary to manage the crisis on the one hand and the communication concerning the crisis on the other - the interest in crises more inherently linked to the disclosure and management of information (in which the crisis is strengthened - or even created - by inappropriate communication) has been limited until now. This type of situation, in which physical damage and personal harm are generally quite limited, is increasingly frequent ${ }^{2}$ and has a significant impact on public trust in political and administrative institutions. ${ }^{3}$

This paper does not aim to examine the institutional or organisational causes and issues or the actions of the various people involved in this particular crisis. Rather, its objective is to identify the characteristics of and errors linked to this type of crisis from a mediacommunication perspective - thus focusing on the type of external perspective that people may have, in order to develop strategies and tools that will make it possible to manage crises 
in such a way as to avoid harming the reputation of the institutions or organisations involved (Barton, 2001; Coombs, 2007a; Coombs, 2010). As Pearson and Mitroff (1993) and Sturges (1994) suggest, one of the primary objectives of crisis management is to maintain an organisation's image - i.e. the public perception of the organisation (Coombs, 1995).

After briefly summarising the literature on crisis communication (part 1) and outlining the methodology of this study (part 2), this article outlines the various phases of the University of Geneva crisis (part 3), analyses the characteristics of the crisis (part 4) and the errors committed (part 5) and concludes with the lessons to be learned from the crisis (part 6).

\section{Crisis management and communication}

A crisis is defined by Crozier (1991) as the "change in all parameters of the physical and human environment in such a way that points of reference no longer exist and people no longer know how to behave" [translation]. A crisis is therefore characterised by a breakdown in normal functioning and leads to strong feelings of uncertainty to which it is difficult to find answers. However, a crisis is perceptual: "It is the perception of stakeholders that help to define an event as a crisis” (Coombs, 2007a, p. 3). From a more analytical perspective, an organisational crisis can be defined by different characteristics (see Coombs, 2007b; 2010; Fearn-Banks, 2007; Zaremba, 2010). The crisis affects the organisation as a whole, not just parts of it, including the following factors:

- The causes may be known, but they cannot be predicted and take the organisation by surprise, i.e., "[a] crisis is unpredictable but not unexpected” (Coombs, 2007a, p. 3);

- The consequences put the organisation's survival at stake;

- Both within the organisation and outside of it, people's perceptions override the facts;

- Requests for information and explanations go beyond the nucleus of those who are directly concerned and there is a strong external pressure on the organisation from all stakeholders.

While the crisis itself requires professional management to identify appropriate technical solutions (provide aid, help individuals in difficulty, identify and find a solution to a technical failure, etc.) and restore things to their normal, pre-crisis way of functioning, the communications surrounding the crisis take on a particular scope and extend beyond the crisis itself, both in terms of time and of the people involved. According to most authors, good crisis management requires good communication (see Anthonissen, 2008; Coombs, 2007a; Fearn-Banks, 2007; Horsley \& Barker, 2002; Ulmer et al., 2007; 2009). Thus, “[a] crisis compels organizations to communicate with various audiences in order to limit the damages that may be caused by a crisis. The quality of these communications can ameliorate or exacerbate the situation” (Zaremba, 2010, p. 21). Similarly, John Penrose (2000) emphasises that without appropriate communication, a crisis management plan is useless.

The evolution of crisis communication is closely related to that of media and technology and to their liberation from political control. Crisis communication gained in importance as early as the 1960s and 70s and, with the development of continuous and simultaneous information (the Internet), coupled with strong competition within the media basically became essential for any organisation facing even minor crises.

According to Revéret and Moreau (1997) and Libaert (2001), a number of elements underscore the importance of using appropriate communication in crisis situations including the following. 
- Many members of the population are directly concerned because they or people to whom they are close are involved. They may also feel concerned because certain values or basic rules have been violated. In these types of situations, people feel that they have a legitimate right to obtain information and answers. Crises are likely to touch an increasingly large percentage of people, given the context of globalisation, the fact that exchanges are not only economic but also social and cultural, and the speed at which communication travels.

- Many different players become involved, providing their own interpretations of events and their own visions of what should be done. Whether from a professional or political perspective, many people who would not normally express their views about the organisation are likely to take advantage of the crisis to get media coverage (as experts, to defend values and propose general solutions, to increase their own visibility or that of their organisation, etc.).

- The organisation's reputation and its role in society are very important when it comes to crises and crisis communication. On the one hand crises damage reputation and such changes can affect how stakeholders interact with the organization (Barton, 2001; Coombs, 2010; Dowling, 2002). However, on the other hand - and regardless of whether an organisation's reputation is good or bad - the higher the notoriety of the organisation the more likely it is that media and the population in general will follow the story.

- The pace of communication concerning the crisis also plays a significant role. While the pace of crisis management tends to be determined by the circumstances of the crisis itself (accident, pollution, technical failure, etc.), crisis communication is largely determined from outside the organisation by the pace of media coverage and of the other main players involved.

- The organisation's traditional channels of communication rapidly become saturated. These channels are accustomed to responding to "normal” media attention, but not to high volume, continuous (day and night, weekends), and insistent demands, particularly since these channels often have no information to provide to the media.

- The organisation must provide specific and quick responses. As Leonard Saffir and John Tarrant (1996) have emphasised, the timing of a response to a crisis is critical. Although it is often difficult to determine the exact cause of an accident or incident, the organisation must provide whatever information it has at its disposal and be particularly careful not to give the impression that it is hiding information. This is because "[t]he media and the public may suspect that the company is trying to cover up something or that it simply does not care" (in Horsley \& Barker, 2002, p. 409). Lack of information from a company spokesperson also leads to rumours and speculation, which can have a lasting negative impact on a company (Horsley \& Barker, 2002; Seigenthaler et al., 2008; Xenou \& Sánchez, 2008). It is obviously important, however, to only provide information that has been verified and validated and to avoid at all costs advancing any hypotheses which may be taken for fact and then later invalidated.

Communication will fundamentally shape public perception of the crisis and the organisation involved in the crisis (Russ, 1991). Information that is regular, accurate, complete, and, if possible, personalised (i.e., provided by one person speaking on behalf of the organisation) makes it possible to reduce uncertainty, limit the risk of too many external players becoming involved, and avoid damage to the organisation's reputation and the population's trust in it (Coombs, 2007a; Hoggan, 1991; Lerbinger, 1986; White \& Mazur, 1995). 


\section{Methodology}

The 2006 expense claims crisis at the University of Geneva was chosen as a case study for several reasons. First, the institution has traditionally enjoyed a solid reputation, both academically and in the public eye. Thus, the public expects a certain rectitude from this institution. Second, this crisis had serious consequences that damaged the institution, leading to the resignation of its executive board and to legislative reform that was not completed until the end of 2008. The fact that the crisis was recent and received such strong media coverage, along with the numerous analyses and commentaries that came from the main 'actors' involved in the crisis, make for a wealth of documentation on the topic. Finally, the case study demonstrates how an initial problem or incident can escalate because of failures on management's part to adequately identify and address the matters at hand, including a lack of effective communication.

In terms of communication, several important issues can be identified. There was wide discrepancy between the rumours and hypotheses that circulated and the real situation in this case. Therefore, the events are only partially responsible for the major crisis the institution eventually faced; instead, it was the lack of reaction to the events, the lack of acknowledgement of the events, and the attitude adopted by the university authorities as the crisis unfolded that fuelled the crisis.

Two types of data were used in carrying out this research: data on the events that took place and data on the media communications surrounding it. For the chronology of events, the following documents were consulted and analysed:

1. Official documents and reports: audit reports and the report on the general inquiry into the University;

2. Official communications: press releases from the University of Geneva, the department of education, and the chancellery of the state of Geneva during the period under investigation.

In terms of media communications, given the large quantity of articles, programmes, and programme sequences devoted to this topic, we limited ourselves to the main media that were accessible and that played a determining role in the crisis, namely articles published in the following newspapers:

- La Tribune de Genève, the main regional daily for Geneva;

- Le Temps, a supra-regional daily reference newspaper; and

- Le Matin and Le Matin Dimanche, respectively a daily and a Sunday paper along the lines of a tabloid.

La Tribune is the main daily newspaper in Geneva, while Le Temps, Le Matin, and Le Matin Dimanche cover the entire French-speaking region of Switzerland. Since this crisis took place mainly in Geneva, and since it was situated within a context of similar affairs also revealed in the state of Geneva, we did not analyse any articles that appeared in newspapers in the rest of French-speaking Switzerland or any German or Italian language papers.

Although there was radio, television and internet coverage of the events, they were not the sources that disclosed the information and therefore were not included in the analysis. Each time the topic was covered in one of the newspapers used for the study, we considered it a contribution, whether it took the form of an article, an editorial, an interview, an analysis, or a 
commentary. This basic breakdown was influenced neither by the length and content of the publication nor by its position in the paper.

The period of analysis extended from April 9, 2006 to December 31, 2008. The publications were collected from Lexis Nexis electronic databases and from the archives of the Tribune de Genève website.

During the period of the crisis itself (from April 9, 2006, to February 8, 2007), a total of 92 publications either covered or made reference to the topic. After this period (from February 9, 2007, to December 31, 2008), a total of 25 publications referred to the crisis.

\section{Description of the University of Geneva crisis}

\subsection{Structure of the crisis}

Scholars have created many classification schemes for crises (see An \& Cheng, 2010; Coombs \& Holladay, 2004; Egelhoff \& Sen, 1992; Marcus, 1991; Pearson \& Mitroff, 1993; Zaremba, 2010). These typologies consider a variety of dimensions, e.g. internal-external, violent-nonviolent, severe-normal damage, technical-sociopolitical failure, concrete-diffuse victims, and objective-subjective.

The expense claims crisis at the University of Geneva is unique because it was caused primarily by the extremely poor management of the misdeeds and how they were communicated, as well as by the resulting dynamics between the university and the media. Because it was not a case involving an accident or a natural catastrophe - both of which make it necessary not only to communicate about the event but also to manage the event itself in order to limit the consequences or the number of victims - we therefore propose a structure for this crisis that consists of three distinct phases:

- Crisis development: the crisis began with the revelation by the press of financial irregularities within the university. It got fully underway when, through political intervention, legal action was requested.

- The acute phase: over the following weeks, a series of new events were revealed, each interpreted as being more serious than the other. The university no longer had any control over the information. The press imposed its agenda. This phase ended with the crisis coming to a head when basically all of the elements that created the scandal had been exposed and, as the ultimate consequence, the executive board resigned en masse.

- The recovery phase: media interest waned and the university regained control over the communications agenda. The crisis ended with the conclusions from the general inquiry into the university, which shed light on the whole affair. The case was closed.

\subsection{Crisis development}

The crisis developed between April and July 2006. Until the submission of the report on the general inquiry into the university, media coverage during this period revealed not only the extent of the university's organisational and institutional dysfunctions but also the fact that the university's governing bodies had been aware of the situation for quite some time. This revelation emphasised the lack of reaction on the part of these bodies and this, in spite of the various reports that had been written much earlier.

In September 1996, as part of a general audit of the state of Geneva accepted by popular vote, a first audit ${ }^{4}$ dealing with the activities of university staff revealed a lack of transparency and called for more accountability. This recommendation was not implemented, however. 
In October 2001, aware of a certain number of transgressions by the university's management, the administrative director wrote his own report, denouncing their dysfunctions. The rector did not send the document to the administrative service of the department of education or to the financial inspection agency for the state. The minister of education in office at the time of the crisis found out about the report in April 2006.

In October 2003, the university's administrative director ordered an investigatory audit to be carried out by a second consulting firm, ${ }^{5}$ without the knowledge of the executive board. Serious irregularities regarding expense claims were brought to the fore by the audit report (hereafter referred to as audit 04/01). The rector at the time of the crisis, who had had the report since the beginning of 2004, filed the document without having read it. The administrative director then ordered an audit from the same firm, focusing on the reimbursement of fees ${ }^{6}$ (hereafter referred to as audit 04/02). The report was sent to the state's financial inspection agency, and then, at the end of 2005, to the head of university affairs at the department of education, who forgot to inform the minister.

\section{The development of the crisis}

At the beginning of April 2006, the press obtained the special 04/02 audit report held by the financial inspection agency for the state. The April 9 edition of Matin Dimanche exposed the case of a penal denunciation and presented several examples of irregular expense claims. When asked to comment on the report, the minister of education denounced this type of practice, stating, however, that it was "reassuring that the university itself had mandated a fiduciary to shed light on the actions it suspected".

\section{The crisis begins}

On April 10, 2006 Le Temps and La Tribune de Genève also published the story. The rector was quoted in both newspapers. He downplayed not only the extent of the irregularities but also their significance. He assured people that the situation was under control and criticised the media's attitude: "I've noticed that the media attention we receive focuses on this type of affair. They are paying more attention to the university now than if one of our professors had won the Nobel Prize.”

On April 13, La Tribune de Genève published an analysis of the contents of the report: "There is one word to describe the university's accounting policies: amateurish." The institution's financial management as a whole was portrayed as being both imprecise and illegal.

In the April 15 edition of Le Matin several political and economic personalities criticised the flippant nature of the executive board's reaction regarding the irregularities and questioned its claim of having taken the necessary measures on its own.

On April 20, the minister revealed to the public prosecutor the case brought to his attention by the rector in March, revealing at the same time all of the situations that might constitute penal offences. Four more cases were revealed. He also sent a letter to the rector, requesting that he "hasten to order a new audit to be done by a fiduciary" ${ }^{7}$, on travel and hospitality expenses for the 2005 fiscal year in order to determine the effectiveness of the new system implemented after 2004”.

On April 22, following the publication of the report for 2004 by the state's financial inspection agency, the newspapers discovered that it was not a matter of one isolated case but that five cases had been exposed and that the irregularities were widespread and recurrent 
throughout the institution. The attitude and lack of firmness on the part of the rector were once again vehemently criticised by the media.

The acute crisis

On April 24, after an in-depth analysis of the contents of the report by the state's financial inspection agency and a demand for further information from the university, the executive board brought the 04/01 audit report to the minister's attention. Among other things, this report mentioned irregularities regarding incidental earnings for teaching staff, the use of private funds to finance salary top-ups, and the repurchasing of contingency payments.

On April 26, the state government decided to launch a general inquiry into the University of Geneva. This inquiry was to be carried out by a former minister and public prosecutor from state another Swiss state.

By April 28, the press was aware of the 04/01 audit report, and the affair became a true scandal. Le Matin ran the title, "University: Panic on board", and following the discovery of an incriminating audit that had until then been "hidden" from political entities and the launch of a general inquiry, asked "just where the fraud scandal at the University of Geneva [would] end up". Rather than organising a "witch hunt" to find out who had exposed the problem, the rector took responsibility and offered to resign. The government asked him to keep his position, declaring that it still had full confidence in him. Dogged by relentless reporters, the rector announced that the university's management had decided to no longer comment on the affair.

Although the executive board had indicated a few days earlier that it would no longer comment on the affair, some executives of the University continued to speak with the press.

On May 11, the university appointed a communications expert, who was promptly interviewed by Le Matin: "The university refuses to comment. Is this a good strategy? [...] before communicating with the outside, it is necessary to be strong on the inside [...] otherwise communications go every which way". The same day the office of the public prosecutor decided that the events were serious enough to justify opening a preliminary penal investigation into false receipts, fraud, abuse of authority, and disloyal management of public interests.

On May 13, Le Matin raised questions about the circumstances under which the 04/01 and 04/02 audits were carried out, as well as about their conclusions. The university still refused to comment. The newspaper turned to anonymous sources: "A state grant was allegedly misappropriated [...] to pay salary top-ups! According to our sources, more than 700,000 francs $^{8}$ are involved in the affair, and the misappropriated funds were meant to be used for AIDS research.”

On May 17, the minister of education sent the 04/01 and 04/02 audit reports to all members of parliament of the state of Geneva.

On May 18, the parliament postponed two projects modifying measures regarding incidental expenses in the law on the university, as well as the creation of a new institute until the September 2006 parliamentary session.

On May 19, a headline in Le Matin read, "University in a shambles! ... The audit hidden by the university has finally surfaced. The evidence is damning”. The press obtained the 04/01 audit and revealed the scandal in its entirety. Not only was the abuse alarming in terms of numbers, but it also appeared to be widespread and recurrent, and it seemed that the department of education had known about it since the autumn of 2003. The minister of 
education in office at the time of the audit also spoke out. She defended herself by saying that she had never been lax in her management of problems.

On June 30, the intermediate report for the general inquiry into the university was submitted to the state government, which decided to communicate only the main points, "in order not to compromise the administrative and penal inquiries". The report noted a "slackening discipline" amongst some professors and a very vague form of management in the institution as a whole. Following the findings of the intermediate report, the state government decided to extend the inquirer's mandate to November 30, 2006. “The university's governance being the most serious problem and the one most urgently in need of being resolved", it decided to create an external committee to write a draft for the law on the university.

All of the daily papers had something to say. Le Matin ran the following headline: "University: sweep-up job on the horizon". Le Temps noted that the affair no longer resembled the "isolated management problem that the rector spoke of recently". The socalled expense claims scandal and other accounting aberrations have brought to light a situation that is concerning enough to warrant a full-scale reform by the state government.

The primary conclusions of the accounting audit for 2005 carried out upon the request of the minister of education on April 20, 2006, would bring to light certain irregularities committed by management. The case was deemed important enough to be communicated to the public prosecutor before the conclusion of the audit. In reaction to these suspicions, the entire executive board resigned in copore on July 11.

\section{Recovery}

Following the executive board's resignation, the government of Geneva had to appoint an interim management team. On July 26 and 27, Le Temps and La Tribune de Genève commented on the state government's choices. A former dean of the university was appointed rector for 10 months. The new management team and the minister of education tried to sound reassuring: "We have found a gem from the inner circle." La Tribune de Genève ran the following headline: "The new head of the university comes with a scandal-free guarantee". A former federal minister and president of the confederation was appointed head of the committee in charge of reforming the university.

In September 2006, as the executive board ad interim began the new university term, the interim rector reiterated the team's ambitious objectives in La Tribune de Genève and Le Temps: "I expect a heightened sense of responsibility from all of my colleagues while they are under my authority. Every franc allocated to the institution must be a good investment". The new rector and his team first promised efficient and transparent management, as well as "absolute discipline" within the university.

On December 20, 2006, a new rector was appointed; he was to take office on July 15, 2007. The candidate, a member of the "inner circle", was the former vice-rector and former vicedean of the university. In Le Temps and La Tribune de Genève, the minister of education explained that the Geneva state government had opted for "caution" and "solidity". For his part, the soon-to-be rector stated that the situation was far from being catastrophic and that the institution was well on its way to recovering: "There is no denying that there are difficulties, but there are other elements to consider: the teaching and research at the university are of a very high quality”.

On January 17, 2007, the final report on the general inquiry into the university was submitted to the state government. Its conclusions minimised the extent of the fraud, but deplored the university's management dysfunctions, stating that the school's governance systems must be 
entirely revised. The report also shed light upon the content, execution, and transmission of the various successive audits, indicating that the total amount of the fraud was in the region of 10,000 Swiss francs. ${ }^{9}$ The irregularities highlighted by the various audits were mostly administrative in nature, due to negligence, a lack of discipline, and, in exceptional cases, a desire for illegitimate enrichment. Only two of the penal denunciations were held by the judge for further investigation. The report states that no intentions to deceive or to gain wealth had been established. The vice-rector whose alleged implication had led to the fall of the executive board was exonerated; the case against her was dismissed by the public prosecutor's office at the end of the month.

\section{Post-crisis}

On November 30, 2008, the new law, which provided the university with more autonomy in terms of political power and strengthened the executive board, was passed by popular vote with an overwhelming $72 \%$ majority of Geneva's population voting in its favour.

\section{Analysis of the characteristics of crisis communication}

As explained earlier in this article, the situation described in section 3 has most of the main characteristics of what constitutes a crisis. We will not attempt to identify and analyse all of these characteristics here, but we will illustrate the main ones.

\section{Interference from multiple players}

This is one of the characteristics that make crises very difficult to manage: whether actively or just in response to media requests, many different people will express their opinions about the crisis or connected topics (Seitel, 1983). In this case, the players included several university governing bodies (the executive board, administrative management, the university senate), the university staff, the minister of teaching and research, several other state ministers, members of parliament, rectors of other universities, and others.

With so many people involved, it is easy to find contradictory remarks or to reveal some particular aspect that had perhaps been forgotten before. In a crisis situation, statements expressed by these various players often carry more weight than the official statements coming from the organisation itself, particularly if the organisation has lost some of its credibility. It is therefore crucial that the organisation be beyond reproach in terms of communication, so that its voice will continue to be heard and so that it can serve as a reference for the media, at least when it comes to establishing the facts: "By appointing one spokesperson, to handle all communication, an organization refrains from releasing confusing message from many sources” (Pinsdorf, 1987, p. 43). For this reason, it is important to always repeat the facts as they are known, to stick to them, to invalidate any statements that are not true, and to try to set the following guideposts for communication (Clampitt, 1991; Garvin, 1996). In the absence of these elements, it is the statements made by other players that will be repeated by the media and assimilated by the population as truth. In these cases, the media reveals the information without identifying its sources.

\section{Exteriority in crisis management}

The pace of any crisis is generally dictated by a series of events as the drama unfolds, and the organisation concerned often has no choice but to adapt to this pace, as well as to that of the media, as it tries to avoid any dissonance, e.g. by respecting a certain grieving time for families before entering into heated debates. In the case of crises that are more specifically related to the disclosure of information, it is the nature of the information that dictates the pace of the crisis if the organisation has lost control over how it is conveyed (see Robertson, 2012). 
The crisis at the University of Geneva stemmed mainly from the fact that the institution's governing bodies only partially acknowledged the existence and the importance of the criticisms being made and, moreover, failed to manage the flow of information concerning them. It is even quite likely that, had the university made public all of the reports that it had in its possession and provided a list of measures it intended to take to remedy existing dysfunctions, the crisis would not have reached the same scale and would have been over in a matter of days or weeks. This would have made sense, particularly since the university could have guessed that the media either already had or would eventually have access to the reports in question. When we examine how the crisis unfolded, it is evident that it is the information that appeared in the media that dictated the pace of the crisis, at least up to the end of the acute phase (the resignation of the executive board). An example that supports this was the executive board's decision to no longer comment on the crisis until the submission of the independent expert's report - a decision that the executive board itself could not uphold due to the articles published in the meantime and to the necessity of providing basic information or commenting on other information.

Once the recovery phase was underway, we can see that the university once again took over the management of most of the communications; articles about the dysfunctions, other than as part of official communiqués, became rare. The proactive nature of the communications, the more technical and responsible tone they took on, and the renewal of confidence in the academic authorities - i.e., the new executive board - explain this reversal to a large extent.

\section{Disturbance in the normal way of functioning}

One characteristic of a crisis is that it affects the entire organisation, not only the departments or individuals directly involved (Fearn-Banks, 2007). Furthermore, the whole organisation is influenced by the pace of the crisis and no longer functions by the same procedures, norms, or habits to which it is accustomed.

In the case of the University of Geneva (although it may be difficult to examine this aspect through the articles that appeared in the press) the entire organisation and all of its associates were affected by the crisis, which occupied the minds of individuals in the institution and impacted all of its activities. For example, the creation of a faculty of environmental science and sustainable development, which was to be made into an institute, was put on hold by the ministry in charge for the duration of the crisis. Another example can be found in an excerpt from an article published in the May 5 edition of Le Temps: "A probe into several faculties reveals a general sense of unease. All professors interviewed by Le Temps speak of a heavy and unpleasant atmosphere that is rife with suspicion. Some faculties have organised crisis meetings to defuse nascent controversies”.

\section{The lumping together of criticisms}

In a crisis, the lumping together of facts, rumours, and hypotheses, and the absence of any hierarchy or structure in terms of the critical events, contribute to people's sense of uncertainty and to the arrival of new players on the scene (Coombs, 2007a; Ulmer et al., 2007). For example, it is interesting to note that some very different problems were placed under the same general label of "dysfunctions": false expense claims of a penal nature, the disregard of rules for filing expense claims, the retrocession of incidental earnings, the university's payments to guarantee the professional contingency of certain professors, the financing of doctoral students hired with the national fund for scientific research, and so on. Although dysfunctions may have been observed in most of the cases, the causes, players, and implications were different each time. Similarly, the seriousness of the offences are also often lumped together. It is not the same thing to file a false expense claim, e.g. by passing off 
personal expenses as professional ones or by falsifying documents, as it is to disregard administrative norms when filing a normal expense claim, e.g. by failing to sign or have documents stamped, having payments that exceed authorised amounts, failing to include proof of payment, etc.. The first case is a penal offence concerning one person who has misappropriated funds for private use, whereas the second case is a matter of administrative problems (violation of rules, vague and easy-to-ignore rules, absence of rules, etc.). The problem is therefore an administrative one and requires not a judicial decision but a more professional management of affairs at the administrative level.

However, as crises are characterised by the predominance of emotions over facts, the facts themselves are not structured; all misdeeds or errors are placed on the same level, which of course generally increases the scope of the crisis and the reactions of those who have been unjustly attacked.

\section{The discovery of similar events in other institutions}

One element observed in many crises is that they can be intensified by the discovery of similar events in other organisations, or by updates on similar situations already known to the public (Libaert, 2001; Revéret \& Moreau, 1997); it is as if it were not a matter of isolated events, but rather of a series of events, a widespread behaviour, or a characteristic of the system itself.

Several similar affairs were brought to light in the Geneva region around the same time period. On May 22, 2006, a candidate for mayoral of Geneva was accused of abuse of authority in the case of several dozen cancelled parking fines. Around the same time, suspicious expense claims were discovered in the police force, and accounting irregularities were found at the authorisations and patents office. On May 29, Le Temps ran this headline: "A tarnished image for Geneva the scandalous". The article also made links to an affair that had made the headlines in 2005. A disciplinary inquiry had been launched against two members of the Geneva city council for the disloyal management of public interests and false receipts. The city allegedly lost up to 25 million Swiss francs ${ }^{10}$ in the affair. ${ }^{11}$ Given that, during the same period, a professor of medicine at the University of Lausanne had been denounced for the misappropriation of several million francs for the private purchase of art books, it is easy to see how many citizens - either unable or unwilling to make the effort to differentiate between individual and collective behaviours, fraud and dysfunction, and specific cases and system management - would get the impression that their public administration had little respect for rules, or even that it was arrogant and corrupt.

\section{Development of rumours and hypotheses in the absence of facts}

As the specific facts are often not known at the beginning of a crisis (the circumstances or causes of an accident are often not known, all the information is not always available, etc.), there is a very high risk that rumours will spread and hypotheses will be formulated, particularly since the media abhors a vacuum and cannot tolerate the absence of plausible explanations. Communication also needs to be proactive and clear to avoid rumours and speculation (see Xenou \& Sánchez, 2008). When there is no information offered by the organisation, the media will seek opinions, ideas about the causes of the crisis, and other input from a wide array of experts, individuals who know the organisation, or other people who feel that they have something legitimate to say, such as political leaders or the heads of civil society organisations. This is what the media did in this case, especially after the university refused to continue commenting on the situation. 


\section{Analysis of communication errors}

While it is almost always impossible to prevent a crisis from emerging and developing, the violation of certain basic rules can lead to errors that aggravate and prolong the crisis and that undermine the credibility of those involved in it. In particular, Robertson empirically demonstrates that withholding information leads to "more media coverage, keeping negative information longer in play and raising the odds of reputational damage" (2012, p. 15). From a symbolic perspective, crisis-response strategies should seek to protect the organisational image (Coombs \& Holladay, 2010; Dionisopoulos \& Vibbert, 1988).

\section{Identification of the crisis and underestimation of the risks}

Crises are symbolic as well as objective (Coombs, 2007a). Although it is relatively easy to identify the risk of a crisis emerging in cases concerning catastrophes, serious accidents, or major incidents, it is not always so for situations in which the crisis stems from successive disclosures of information. Several elements should have alerted university authorities to the risk of a crisis in this case, however, including:

- The institution's reputation: The University of Geneva recently celebrated its 450th anniversary, and the institution is renowned, both nationally (having the second largest student population in Switzerland) and internationally. The greater an institution's renown, particularly in the case of public institutions, the more likely are the media and the population to be interested in problems concerning it.

- The university authorities knew of the existence of the reports and the dysfunctions: the chances of such documents being given to the media either officially or surreptitiously were very high, as many examples illustrate. In such a case, the institution must assume that this type of document or this information may be made public at any time.

- Similar affairs had surfaced a few weeks earlier and had been the subject of intense media coverage: for example, the former mayor of Geneva had admitted to cancelling fines that he had received, and the question of the legality of this action was the subject of an inquiry.

- Questions concerning wrongfully paid benefits, regardless of their value, are always likely to spark the interest of the media and its readers or listeners. These topics are in fact covered by the media on a regular basis.

There is, of course, no way to be certain that a crisis is imminent, but the organisation must be able to analyse the risk of a crisis developing and act accordingly, which was evidently not done in this case.

\section{Refusing to comment}

Watzlawick's famous maxim, "one cannot not communicate”, also applies to crisis situations because every action and attitude is interpreted as a form of communication. Noncommunication therefore conveys a message that can be interpreted in many different ways (Coombs, 2007a; Ulmer et al., 2007).

This is a classic and extremely harmful error because in crises the silence of the main player is almost always compensated for by the voices of other players or quite simply by the media itself (Coombs, 2007a; Fearn-Banks, 2007). To think that an absence of communication will lead to a loss of interest by the media is a serious mistake because this type of situation encourages the development of hypotheses and rumours, tends to increase media pressure for more information, and can be perceived by the public as being problematic (Horsley \& Barker, 2002; Libaert, 2001; Zaremba, 2010), particularly when the matter concerns a public 
institution, which is accountable to the public. Frohlichstein (1998), for example, suggests that by responding quickly to the media, an organisation demonstrates both that it is concerned and that it is open with the public.

In the University of Geneva crisis case, during an April 28 interview with La Tribune de Genève and following a decision of the state government to call for an administrative inquiry, the rector stated, "We have decided to no longer comment on this topic", at least until the release of the inquiry's results, scheduled for June 30. This decision also applied to the deans of faculties, who were given corresponding orders. This silence, which was actually broken by the rector on June 2, created more problems than it solved:

- The media came up with its own hypotheses: faced with an absence of information, and since rumours implicated a member of the executive board, La Tribune de Genève raised suspicions in an article published on May 4 about a vice-rector who had previously been the dean of the faculty of medicine. The suspicions were later dropped, but since the executive board was not commenting on the situation, the vice-rector in question did not have the chance to invalidate these hypotheses.

- The field was filled by other players. It is interesting to note that, although the rector had just announced that he would no longer comment on the topic until June 30, it was a member of the executive board who accepted an interview with La Tribune de Genève on May 4, stating, "I have already told him [i.e., the rector] that he should stop exposing himself. He could have sent those responsible to the front, and he can find as many as he wants. We have no lack of proof. Everything is documented”. Not only did the lack of collegiality amongst members of the executive board decrease its credibility (for the administrative director also expressed his opinions independently), but the comments also encouraged members of the media to increase their search for more information, knowing now that there was documented proof. In fact, they went on to gather information from anonymous sources, which added to the confusion.

Several other people also expressed their opinions during this period: professors from the university who were concerned about the situation, members of parliament who had solutions to propose, etc. All of these opinions fuelled the media debate, but there was no official position to frame the statements in any way.

\section{Denying facts and concealing documents (denial and lies)}

Crises often take on a particularly serious tone when the main players deny the facts at the beginning (Coombs, 2007a; Elmasry \& Chaudhri, 2010; Fearn-Banks, 2007; Marcus, 1991; Zaremba, 2010). Take, for example, the case of the fire in the Sandoz company's Schweizerhalle factory in 1986, which allegedly led to a large number of toxins spilling into the Rhine River. The heads of the company first denied this [ "there is nothing there"], then tried to remove the blame from themselves ["there is something there, but we didn't do it"]. This type of action is catastrophic in terms of crisis communication because the trust is broken between the organisation and the various sectors of the target public. For communication to have the desired effect there must at least be a minimum of trust between the parties concerned.

Of course, there was not a complete denial of the facts in the University of Geneva affair, but there were lies of omission. The executive board was completely aware of the various reports, but only acknowledged their existence as, one by one, they were revealed to the public. This type of action is perceived by the media and the general population as lying, which seriously compromises the credibility of the institution's governing body. 


\section{Downplaying the significance of exposed events}

Without going as far as to deny the facts, many people are tempted to downplay them or their significance, which can be counter-productive since this type of attitude can reinforce people's impression that the institution does not care about citizens' concerns (see Augustine, 1995). In this case, university authorities, and sometimes political authorities as well, tried this tactic often.

When Le Matin published its first article on April 9, the rector acknowledged the problem, but downplayed it at the same time, saying, "The report doesn't tarnish the university's reputation", and "It is only a matter of a few hundred francs". These remarks were not very credible because in the same article, the newspaper revealed that the report it had obtained spoke of abuse in approximately $25 \%$ of expense claims. Furthermore, these same remarks were repeated in articles published throughout the crisis each time a new element was revealed. The rector implicitly acknowledged this erroneous assessment because in an interview that was printed in the June 2 edition of La Tribune de Genève, he stated, "Universities have an ethical role to play [...]. Minor theft is unacceptable in this context. Even if it doesn't happen often, it's more serious than when it occurs elsewhere”.

This attempt to downplay the extent of the dysfunctions and misdeeds was already prevalent before the crisis began because the deanship of a faculty that was concerned wrote the following statement: "[...] and incidentally concern amounts which actually seem quite modest" and "[...] that a more rigorous approach would go against the principle of proportionality regarding other cases of which the faculty and executive board are aware”. These excerpts published in the media reinforced people's impression that the university had a specific notion of the seriousness of the errors committed, as compared to errors committed by other institutions. The communication of blame and responsibility has been much discussed in the literature, and it has been argued for example that the apology is a common element of crisis communication (Bovée \& Thill, 1998; Cain, 1997; Tyler, 1997; Yagoda, 1990). If a company is at fault, its spokespersons repair the company's reputation much faster if they apologize, accept responsibility and show remorse” (Horsley \& Barker, 2002, p. 409).

\section{Neglecting internal communication}

Among those who are affected by a crisis are the institution and its associates. They are asked by their families, friends, and colleagues to express their opinions about the criticisms being made of their institution (Zaremba, 2010). As in the case being examined here, they can also sometimes be suspected of having taken advantage of the system themselves.

Although it is very difficult - impossible even - to inform the institution's associates ahead of time, since the pace of the crisis is set mostly by the media and its revelations, relations between authorities and their associates seem to be characterised by a total lack of communication; this leads to a sense of disappointment and frustration (Mucchielli, 1993) and to a desire to express opinions-particularly in people who are accustomed to speaking to the media and who have many media and political contacts. Many of these individuals will express their opinions either personally or anonymously, such as the professor of medicine, for example, who stated on May 5, "everyone knew there were accounting dysfunctions". That same day, La Tribune de Genève wrote: "Several professors are expressing their dissatisfaction and are commenting on the affair anonymously".

\section{Attacking the media}

Scholars have demonstrated how media naturally feature selected aspects in presenting a story (Yioutas \& Segvic, 2003). Members of the population who are at the receiving end of these stories will focus on these emphasised factors (Druckman, 2001). Although the media 
can at times appear to be insistent, intrusive, and even aggressive, particularly in the case of a crisis, trying to distract the media by placing either part or all of the blame on it, or by directly or indirectly judging the quality of the work it does, should be avoided; this type of behaviour tends to create tension in the institution's relationship with the media and only incites the media to increase its research efforts.

Several remarks made by the academic and political authorities in this case went along these lines:

- “The fact that there are irregularities is shocking [...] but I've noticed that the attention we receive from the media tends to focus on this type of affair". (Statement from the rector on 10.04.06);

- "Nothing is hidden; it's the press that didn't see anything”. (Remark made by the executive councillor for the department following a reporter's question regarding the fact that he had known about the report in 2003 but didn't disclose the information until 2006.)

\section{Seeking vindication and laying blame}

In the midst of a crisis, particularly when no one has an overall view of the information that exists or of the consequences of the crisis, it is important that the institution avoid laying blame too early on, even if it is tempting to transfer media pressure elsewhere. It is very likely that such remarks will eventually be proven false, which reduces the credibility of the person who has made the accusations. Furthermore, strong leadership is usually important during a crisis -leadership which inspires confidence and reduces the sense of uncertainty other players may feel.

Examples from university or political authorities could once again be cited, but this behaviour was also observed amongst the university's professors at the very beginning of the crisis. On April 15, the president of the university senate (assembly of professors) denounced "the paperwork connected with the filing of expense claims" and one professor stressed that "by increasing monitoring, we also increase the risk of skulduggery". These types of remarks, which downplay the seriousness of the events and, moreover, place the blame for errors (some of which were later clearly denounced as being penal offences) on the system does not promote the resolution of the crisis.

\section{Word choice}

It has been claimed that "[c]ommunication is irreversible" (Zaremba, 2010, p. 71). During a crisis, and particularly at the beginning, a few misplaced words can be enough to increase tensions, especially since these words will often be systematically repeated as key reference points by various people. The words chosen by the rector when he said, "It's only a matter of a few hundred francs"; "The affair is preposterous"; "Professors should learn to restrain themselves"; "It is a report that makes the university grow in stature"; "But we are part of the civil service. And this person did not commit any errors in the strict sense of his scientific work. It isn't as if the person in question had cheated on a scientific publication”, and so on, are the types of remarks that would go on to be the subject of numerous criticisms and on which the media and other various individuals would base themselves afterwards. It is these remarks that were later used as reference points to judge the university's ability to admit the existence of the facts, to understand their seriousness, and to take steps toward resolving the crisis. 


\section{Practical applications}

Horsley and Barker give recommendations on how to proceed during crisis events, saying: "after a crisis occurs, prompt, concerted communication stops rumours and speculation; using the media to diffuse information is a key element in maintaining good public relations. Resolving the crisis in an ethical and human manner is crucial” (2002, p. 416). Several lessons concerning the governance of public organisations, crisis management, and crisis communication can be learned from this case study.

In terms of governance, public organisations work in a complex environment in which they are increasingly obliged to be accountable, not only to their regulatory authorities (vertical accountability), but also to an increasing number of players with no hierarchical power (horizontal accountability) (see Zaremba, 2010). For reasons that are mainly linked to governance (lack of clarity concerning power relations between the executive board and the administrative management; lack of clear rules; varied interpretations of existing rules; lack of authority in the application of the rules; a value system in conflict with other public administrations; the competence required to manage such an institution; etc.), the university was not able to manage the different events and problems in a thoughtful and professional manner. If it had, the crisis would not have happened. By implementing a legislative revision process, finally approved by popular vote, the political authorities learned a clear lesson from this crisis and gave the university a modern framework with which to manage this type of organisation.

A second lesson specific to this type of crisis, in which crisis management coincides with crisis communication, concerns the absence of any relationship between the objective seriousness of the events and the scope of the crisis. While some major dysfunctions were noted, revealing a certain laxity in the university's administrative and financial management, only one case ended up being judged as a penal offence. It is therefore not the seriousness of events that provoked the crisis, but rather the lack of seriousness with which they were treated and followed up upon during the years leading up to the crisis, as well as the attitude of university authorities when it was all brought to the attention of the public. When a crisis does not stem from an accident or a serious incident, the management of events and the ability to communicate in a professional manner become particularly determining factors (Anthonissen, 2008; Coombs, 2007a; Fearn-Banks, 2007; Ulmer et al., 2009; Zaremba, 2010). As mentioned above, the crisis would probably have been much smaller if the facts had been communicated immediately and if their importance had not been downplayed.

Crises function under a type of logic that is completely different from that to which organisations are accustomed, and organisations must therefore be able to set up structures rapidly in order to deal with them. Based on the documents studied, the university does not seem to have been able to recognise the crisis as it developed, or to respond with appropriate structures. On the contrary, the role of the media was underestimated, contradictions cropped up within the institution itself, the institution very quickly lost control of the pace of communications, and so on. In this type of situation, the crisis could only worsen and lead to the resignation of the executive board. There are certain rules to be followed, such as acknowledging the particular nature of the crisis; implementing structures and processes specific to the crisis; and adapting the tone, pace, and content of communication (Coombs, 2007a; 2007b; Horsley \& Barker, 2002). These are not new lessons but they are worth repeating.

Finally, an organisation cannot afford to not communicate (Coombs, 2007a; Seigenthaler et al., 2008; Ulmer et al., 2007). In the University of Geneva's case, the institution found itself 
faced with the dilemma of either communicating, and thereby revealing potentially harmful information, or not communicating, thereby running the risk of having the information transmitted to the media through a third party -which is what ended up happening. Especially when it is a public organisation that is heavily involved in the local context (the academic, political, social, and media elite know one another and interact on a daily basis), it essentially goes without saying that the information will eventually make its way into the hands of the media. Consequently, non-communication is not a tenable strategy. Furthermore, noncommunication leaves the doors open for other players who may not always be wellintentioned to put forth a multitude of hypotheses, which will then be transformed by rumour or malevolence into accepted facts. The university should therefore have proactively revealed the reports it had in its possession (particularly the fiduciaries' reports ${ }^{12}$ ) and done its best to ensure an ongoing dialogue with the media (although it is true that this type of dialogue becomes impossible when there is a lack of mutual trust). To communicate does not necessarily mean to make all events immediately public (particularly if the crisis stems from the fact that events are out of control to begin with), but rather to ensure that the organisation continues to be recognised as a reliable partner in establishing the facts, assuming the corresponding responsibility, and finding solutions. If, however, the organisation expresses itself in a disorderly and contradictory fashion, and then stops expressing itself altogether, it can no longer assume its role with other players.

\section{References}

An, S, \& Cheng, I. (2010). Crisis communication research in public relations journals: Tracking research trends over thirty years. In T. Coombs \& S. Holladay (Eds.), The handbook of crisis communication (pp. 65-90). Singapore: Blackwell Publishing.

Anthonissen, P. (Ed.). (2008). Crisis communication: practical PR strategies for reputation management and company survival. London: Kogan Page.

Augustine, N. (1995). Managing the crisis you tried to prevent. In Harvard business review on crisis management (pp. 1-31). Boston, MA: Harvard Business Press.

Barton, L. (2001). Crisis in organisations II ( $2^{\text {nd }}$ ed.). Cincinnati, OH: College Divisions SouthWestern

Bovée, C., \& Thill, J. (1998). Business communication today. Upper Saddle River, NJ: Prentice Hall.

Cain, T. (1997, August 15). Why the old rules won’t defuse a modern crisis. Australian Financial Review, p. 65

Clampitt, P. (1991). Communicating for managerial effectiveness. Newbury Park, CA: Sage.

Coombs, T. (1995). Choosing the right words. The development of guidelines for the selection of the 'appropriate' crisis-response strategies. Management Communication Quarterly, 8, 447-476.

Coombs, T. (2007a). Ongoing crisis communication, Planning, Managing, and Responding ( $2^{\text {nd }}$ ed.). Thousand Oaks, CA: Sage.

Coombs, T. (2007b). Protecting organisational reputation during a crisis: The development and application of situational crisis communication theory. Corporate Reputation Review, 10(3), 163176.

Coombs, T. (2010). Crisis communication and its allied fields. In T. Coombs \& S. Holladay (Eds.), The handbook of crisis communication (pp. 54-64). Singapore: Blackwell Publishing.

Coombs, T., \& Holladay, S. (2004). Reasoned action in crisis communication: An attribution theorybased approach to crisis management. In D. Millar \& R. Heath (Eds.), Responding to crisis: A rhetorical approach to crisis communication (pp. 95-115). Mahwah, NJ: Lawrence Erlbaum.

Coombs, T. \& Holladay, S. (Eds.). (2010). The handbook of crisis communication. Singapore: Blackwell Publishing.

Crozier, M. (1991). La gestion de crise. Les cahiers de la sécurité intérieure, 6.

Dionisopoulos, G., \& Vibbert, S. (1988). CBS vs. Mobil Oil: Charges of creative bookkeeping in 1979. In H. Ryan (Ed.), Oratorical encounters (pp. 241-251). New-York: Greenwood.

Dowling, G. (2002). Creating corporate reputations: Identity, image, and performance. New York: Oxford University Press. 
Druckman, J. (2001). The implications of framing effects for citizen competence Political Behavior 23(3), 225-256.

Egelhoff, W., \& Sen, F. (1992). An information-processing model of crisis management Management Communication Quarterly, 5, 443-484.

Elmasry, M., \& Chaudhri, V. (2010). The press as agent of cultural repair: A textual analysis of news coverage of the Virginia Tech shootings. In T. Coombs \& S. Holladay (Eds.), The handbook of crisis communication (pp. 141-158). Singapore: Blackwell Publishing.

Fearn-Banks, K. (2007). Crisis communications: A casebook approach $\left(3^{\text {rd }}\right.$ ed.). Mahwah, NJ: Lawrence Erlbaum Associates.

Frohlichstein, T. (1998, April 1). Get information to the media quickly St. Louis Journalism Review, p. 17. Retrieved from http://findarticles.com/p/articles/mi_hb6666/is_n205_v28/ai_n28703664/

Garvin, A. (1996). The art of being well informed ( $2^{\text {nd }}$ ed.). New York: Avery.

Hoggan, J. (1991). Open door public relations: A new strategy for the 1990s. Business Quarterly, 56(2), 22.

Horsley, S., \& Barker, R. (2002). Torward a synthesis model for crisis communication in the public sector: An initial investigation. Journal of Business and Technical Communication, 16(4), 406440.

Lerbinger, O. (1986). Managing corporate crisis. Boston, MA: Barrington Press.

Libaert, T. (2001). La communication de crise. Paris: Dunod.

Marcus, A. (1991). Victims and shareholders: The dilemmas of presenting corporate policy during a crisis. Academy of Management Journal, 34, 281-305.

Mucchielli, A. (1993). Communication interne et management de crise. Paris : Les éditions d'organisation.

Pearson, C., \& Mitroff, I. (1993). From crisis prone to crisis prepared: A framework for crisis management The Executive 7, 48-59.

Penrose, J. (2000). The role of perception in crisis planning. Public Relations Review, 26, 155-171.

Pinsdorf, M. (1987). Communicating when your company is under siege Lexington, MA: D.C: Heath

Revéret, R., \& Moreau, J. (1997). Les médias et la communication de crise. Paris: Economica.

Robertson, J. (2012). Tell it all: Challenging crisis communications' rules. Public Relations Journal, $6(1), 1-19$.

Russ, G. (Ed.). (1991). Symbolic communication and image management in organizations. Newbury Park, CA: Sage.

Saffir, L., \& Tarrant, J. (1996). Power public relations: How to get PR to work for you. Lincolnwood, IL: NTC Business Books.

Seigenthaler Courtney, E., \& Buitelaar, W. (2008). Negative press and how to deal with it. In P. Anthonissen (Ed.), Crisis communication (pp. 119-131). London: Kogan Page.

Seitel, F. (1983). 10 myths of handling bad news. Bank Marketing,15, 12-14.

Sturges, D. (1994). Communicating through crisis: A strategy for organisational survival. Management Communication Quarterly, 7, 279-316.

Tyler, L. (1997). Liability means never being able to say you're sorry: Corporate guilt, legal constraints, and defensiveness in corporate communication. Management Communication Quarterly 11, 51-73.

Ulmer, R., Sellnow, T., \& Seeger, M. (2007). Effective crisis communication: Moving from crisis to opportunity. Thousand Oaks, CA: Sage.

Ulmer, R., Sellnow, T., \& Seeger, M. (Eds.). (2009). Post crisis communication and renewal: Understanding the potential for positive outcomes in crisis communication. New York: Routledge.

White, J., \& Mazur, L. (1995). Strategic communications management: Making public relations work Wokingham, UK: Addison-Wesley.

Xenou, M., \& Sánchez, N. (2008). A multitude of challenges for the international food sector. In P. Anthonissen (Ed.), Crisis communication: Practical PR strategies for reputation management and company survival (pp. 109-118). London: Kogan Page.

Yagoda, B. (1990). Cleaning up a dirty image. Business Month, 135(4) 48-51.

Yioutas, J., \& Segvic, I. (2003). Revisiting the Clinton/Lewinsky scandal: The convergence of agenda setting and framing. Journal and Mass Communication Quarterly, 80(3), 567-582.

Zaremba, A. (2010). Crisis communication theory and practice. New York: M.E. Sharpe. 
1 The executive board (rectorat) of the University of Geneva is composed by a rector (executive head) and several vice-rectors and deans. They are in charge of the general policy and strategy of the university.

2 Consider, for example, the revelations concerning the British members of Parliament expenses scandal (2009).

3 Although this crisis had important consequences at the institutional level, only a handful of the events ended up being treated criminally. In the end, only one ruling led to conviction; the court decided that for the rest, the amounts were small and had resulted from "written errors" and "lack of understanding". The executive board launched four public inquiries, three of which ended without any disciplinary actions. One inquiry (the one linked to the penal conviction) led to disciplinary action.

4 Andersen audit, September 1996.

5 Special audit report 04/01 by Ernst \& Young (February, 2004)

6 Special audit report 04/02 by Ernst \& Young (July, 2004)

7 Price Waterhouse Coopers report (August, 2006).

8 In 2006, approximately 560,000 USD

9 In 2006, approximately 8,000 USD

10 In 2006, approximately 20,000,000 USD

11 This affair was referred to as the Rue du Stand affair, named for the street where a building was repurchased by the city of Geneva.

12 The state of Geneva has had a law on public information and access to documents (LIPAD) since 2002. The type of documents in this case most certainly fell under the law's jurisdiction, and anyone could have requested them from the university.

* Martial Pasquier is Professor of Public Management at the Swiss Graduate School of Public Administration (IDHEAP), Lausanne. He can be contacted at martial.pasquier@idheap.unil.ch.

* Etienne Fivat is a teaching and research assistant at the Swiss Graduate School of Public Administration (IDHEAP), Lausanne. She can be contacted at etienne.fivat@idheap.unil.ch. 